\title{
Internet of Things (IoT) for digital concrete quality control (DCQC): A conceptual framework
}

\author{
Arka Ghosh $^{1}$, M. Reza Hosseini ${ }^{2}$, Riyadh Al-Ameri ${ }^{3}$, Gintaris Kaklauskas ${ }^{4}$, Bahareh Nikmehr ${ }^{5}$ \\ ${ }^{1,2}$ School of Architecture and Built Environment, Deakin University, Geelong, Australia \\ ${ }^{3}$ School of Engineering, Deakin University, Geelong, Australia \\ ${ }^{4}$ Research Institute of Building Structures, Vilnius Gediminas Technical University, Vilnius, Lithuania \\ ${ }^{5}$ School of Civil Engineering, Iran University of Science and Technology, Tehran, Iran
}

\section{E-mail: 'ghoshar@deakin.edu.au (correspondingauthor)}

\begin{abstract}
Concreting is generally a manual, labour intensive and time-consuming process, putting additional burden on constrained resources. Current practices of concreting are wasteful, non-sustainable and end products usually lack proper quality conformance. This paper, as the first outcome of an ongoing research project, proposes concrete as an area ripe for being disrupted by new technological developments and the wave of automation. It puts forward arguments to show that The Internet of Things (IoT), as an emerging concept, has the potential to revolutionize concreting operations, resulting in substantial time savings, confidence in its durability and enhanced quality conformance. A conceptual framework for a digital concrete quality control (DCQC) drawing upon IoT is outlined; DCQC facilitates automated lifecycle monitoring of concrete, controlled by real-time monitoring of parameters like surface humidity, temperature variance, moisture content, vibration level, and crack occurrence and propagation of concrete members through embedded sensors. Drawing upon an analytical approach, discussions provide evidence for the advantages of adopting DCQC. The proposed system is of particular appeal for practitioners, as a workable solution for reducing water, energy consumption and required man-hours for concreting procedures, as well as, providing an interface for access to real-time data, site progress monitoring, benchmarking, and predictive analytics purposes.
\end{abstract}

Keywords: concrete structure, Industrial Internet, Industry 4.0, sensors, digitization.

\section{Introduction}

Cutting edge technology like bricklaying robots (FastBrick Robotics), automated OH \& S reporting (SmartSite), asset management (AutoDesk Fusion Connect), drone technology for aerial survey and monitoring, embedded technology in building components providing intelligent structural elements (Smart Products) will change the "way of work" across the construction industry. Of these, the application of Internet-of-Things (IoT) can provide solutions for many such issues. It is predicted that IoT will have a monetary impact of saving, up to $22-29 \%$ of the total costs in construction, translated to \$75-96 billion in annual benefits (Ramasundara, Johnson, \& Baumeister, 2018). IoT will ensure high-speed reporting, and hence reducing the cost of communication, will ensure better process control and optimization. Moreover, the considerable amount of data collected makes possible real-time monitoring and analysis at the micro-level, leading to better decision making, accountability and transparency of stakeholders.

Of various construction activities, concrete works are of paramount importance (Jarkas, 2011). Approximately 25 billion tons of concrete is produced annually. The construction industry produces around 1200 MT of construction and demolition waste, a significant proportion of which is concrete waste (Klee, 2009). Poor performance of concrete structures has also received serious attention due to: (1) significant failure events like the infamous Opal Tower incident in Sydney; (2) large amount of waste (Korkmaz, Yakut, \& Bayraktar, 2019); (3) low productivity of concreting activities (Australian Government, 2017); (4) insufficiency of concrete structures durability; (5) environmental disruption, among other issues associated with concreting activities and concrete structure. A brief description of the causes of each problem is presented below (Gardner, Lark, Jefferson, \& Davies, 2018).

The durability of concrete members is affected by many factors, e.g. materials, environment, construction, and design (Pan, Z. Shi, C. Shi, Ling, \& Li, 2017), of which temperature and humidity are critical parameters, controlled by the quality of curing procedures (Ha, Su Jung, \& Cho, 2014). Despite rapid technological advancements, curing of concrete on typical construction projects is still performed by labour-intensive processes like ponding, hosing, steam

(C) 2019 Authors. Published by VGTU Press. This is an open-access article distributed under the terms of the Creative Commons Attribution (http://creativecommons.org/licenses/by/4.0/) License, which permits unrestricted use, distribution, and reproduction in any medium, provided the original author and source are credited. 
or saturated cover materials (Surahyo, 2019). Some improvements have been made by using ultra-fine fog droplets or use of super-absorbent polymers and external plastic sheeting. None of these have gained widespread acceptance across the construction industry, due to high implementation costs and the need for upskilling the on-site workforce (Kewalramani, 2014; Rattanadecho, Makul, Pichaicherd, Chanamai, \& Rungroungdouyboon, 2016; Justs, Wyrzykowski, Bajare, \& Lura, 2015).

Moreover, transportation of concrete faces serious issues like the unauthorized addition of water by transit-mixer drivers to maintain workability and delay concrete setting time. Even the use of retarding agents sometimes are not fruitful due to unforeseen traffic jams or other logistical issues. This necessitates retesting of concrete once it reaches the site to ensure that the requisite characteristics of the concrete mix are maintained (Gao, Zhang, \& Su, 2019; Howes, Hadi, \& South, 2019). This causes undue time delays during construction and sometimes essential quality checks are skipped to achieve the target deadline during peak concreting.

Manual curing causes early-age cracking and ugly water stains which significantly affect the durability and aesthetic appearance of the concrete members. If curing is automated and stable conditions for temperature and relative humidity can somehow be maintained, the durability and aesthetic appearance of the concrete members can be significantly improved (N. Bella, I. A. Bella, \& Asroun, 2017; Ghourchian, Wyrzykowski, Baquerizo, \& Lura, 2018).

Concrete segregation due to improper placing techniques is also a common problem, which decreases the structural integrity of concrete structures. Especially, with the growing use of self-compacting concrete (SCC), monitoring of concrete viscosity level becomes an important issue to provide necessary information to contractors to determine the level of vibration allowable for such high-fluidity concrete (Safawi, Iwaki, \& Miura, 2004). On many occasions, an arbitrary rule of thumb of 28 days is taken, which may not be the actual time for concrete member to fully attain total hydration and gain full strength.

Early formwork removal, where concrete is not adequately hardened, can cause enormous material, labour and machinery loss and damage (Rockstroh, 2018; Samouh, Rozière, \& Loukili, 2015). There is an urgent need for a new methodology capable of monitoring the real-time strength of concrete as per the temperature and humidity, and providing the actual time when chemical curing is totally complete.

Structural health monitoring of large-scale infrastructure such as inverted T-bent caps, dams, and deck slabs of bridges, piers and abutments of bridges also present problems (Song, Gu, Mo, Hsu, \& Dhonde, 2007). It is especially the case for bridge piers and abutments that are located underwater or underground. Traditional inspection methods like $\mathrm{x}$-ray spectroscopy or C-Scan are expensive and sometimes ineffective for large-scale structures.

Despite the synergy between IoT and concrete activities, research into this area has remained in its infancy, where existing studies almost entirely have targeted specific use cases of IoT for concrete, overlooking the broad picture (Wei et al., 2018; Yang, Fan, Kong, Cai, \& Chen, 2018). As such, the potential of IoT for enhancing the concrete supply chain as a whole has been overlooked in the now-available literature. This study aims at addressing this gap. To this end, a conceptual framework for an automated concrete monitoring, placing and curing system (DCQC) is proposed which takes an integrated approach towards the solution of critical concreting issues through digitalization and using smart devices interconnected with one another. This arrangement can generate sufficient data to assist construction managers and personnel in key decision-making and significantly lowering material, labour and energy costs.

\section{Research methods}

The defined objectives of this paper are pursued through "explanation building," namely, conducting a theoretical review, as described in detail by (Paré, Trudel, Jaana, \& Kitsiou, 2015). Theoretical review has as its objective making a contribution to the world of practice, while providing a conceptual framework to guide future research efforts. To this end, the theoretical review formulates required attempts to draw on existing conceptual and empirical studies to provide a context for identifying, describing, and transforming into a higher order of theoretical structure and various concepts, constructs or relationships (Paré et al., 2015, p. 188). The theoretical review procedure is illustrated in Figure 1.

Initially, the critical problems currently facing the concrete industry is identified from recent scientific publications industry reports and informal discussions with industry personnel in this field from all over the world. Next, a survey of available IoT enabling technologies is performed - those utilized in other industries like mining or automobile engineering - to identify the possible merits and demerits of existing technologies. Next, the applicability of these technologies in the construction sector - by identifying successful case studies where IoT has proven useful - is explored, while also seeking to identify potential economic and practical feasibility of these IoT solutions. Finally, a conceptual framework is developed to outline the use of various components of IoT and develop a user-friendly interface to act as a tool for construction personnel, allowing them to monitor various parameters of concrete throughout its lifecycle in real-time, as well as, triggering alerts in case the acceptable thresholds are overrun. 
Identification of critical concreting issues at different stages

- Scientific publications

-Industry Reports

- Informal discussions with

industry personnel

\section{Critical survey of}

available loT

technologies

- IoT enabling technologies

- Pros and cons of various

trending technologies

\section{Applicability in the} concreting sector

- Case studies sucessfully applying loT in Construction Industry - Potential economic and practical feasibilty
Development of a conceptual framework integrating all technolgies

- Developing a userfriendly dashboard for implementing DCQC - Highlighting the key benefits and potential impacts

Figure 1. Research design

\section{Problems with current practices}

A preliminary review of the literature concerning critical issues in concreting operations led to identifying significant problems with current concreting practices, as the items tabulated in Table 1. The issues have been categorized into different stages of concreting operations (both in-situ and pre-fabricated) to get an overview of the burning issues currently plaguing the concreting industry, throughout project delivery. The stages have been highlighted as concrete production at the batching plant or in-situ at the site, transportation through transit mixers, its placing using vibrators and formwork, curing of concrete, and post-construction structural health monitoring stages.

Table 1. Problems plaguing concreting activities

\begin{tabular}{|c|c|c|c|}
\hline Sl. & Stage & Concrete problems & References \\
\hline \multirow{3}{*}{1} & \multirow{3}{*}{ 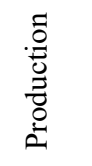 } & Improper $\mathrm{w} / \mathrm{c}$ ratio & (Juliafad, Rani, \& Rifwan, 2019) \\
\hline & & Quality control in real time & (Reiter, Wangler, Roussel, \& Flatt, 2018) \\
\hline & & Material wastage & (Bassani, Garcia, Meloni, Volpatti, \& Zampini, 2019; Sitnikov, 2018) \\
\hline \multirow{6}{*}{2} & \multirow{6}{*}{ 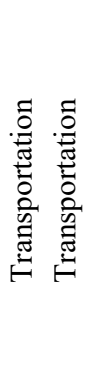 } & Unauthorized addition of water & (Juliafad et al., 2019) \\
\hline & & Climatic conditions & (Afzal \& Khan, 2018; Ghosh, Hasan, Jha, \& Sahoo, 2018) \\
\hline & & Operator skill & (Afzal \& Khan, 2018; Ghosh et al., 2018) \\
\hline & & Traffic conditions & (Afzal \& Khan, 2018) \\
\hline & & Scheduling and routing issues & $\begin{array}{l}\text { (Hasan, Sahoo, Ghosh, \& Jha, 2018; Kinable, Wauters, \& Berghe, } \\
\text { 2014; Sheikh, Lakshmipath, \& Prakash, 2016) }\end{array}$ \\
\hline & & Fleet management & (Ghosh et al., 2018; Niu, Lu, Liu, Chen, \& Xue, 2017) \\
\hline \multirow{4}{*}{3} & \multirow{4}{*}{$\stackrel{\substack{0 \\
0 \\
\frac{\pi}{2}}}{\frac{\pi}{2}}$} & $\begin{array}{l}\text { Improper vibration imparted (over- } \\
\text { compaction/under-compaction) }\end{array}$ & (Howes et al., 2019; Juliafad et al., 2019) \\
\hline & & Concrete segregation & (Gao et al., 2019) \\
\hline & & $\begin{array}{l}\text { Formwork efficiency and sustaina- } \\
\text { bility }\end{array}$ & (Sitnikov, 2018) \\
\hline & & Placement temperature & (Ouyang et al., 2019) \\
\hline
\end{tabular}


Ghosh, A.; Hosseini, M. R.; Al-Ameri, R.; Kaklauskas, G.; Nikmehr, B. 2019.

Internet of Things (IoT) for digital concrete quality control (DCQC): A conceptual framework

End of Table 1

\begin{tabular}{|c|c|c|c|}
\hline Sl. & Stage & Concrete problems & References \\
\hline \multirow{6}{*}{4} & \multirow{6}{*}{ 泀 } & Non curing & (Juliafad et al., 2019) \\
\hline & & Early formwork removal & (Rockstroh, 2018; Samouh et al., 2015) \\
\hline & & Plastic shrinkage & (Bella et al., 2017; Ghourchian et al., 2018) \\
\hline & & Thermal cracking & (Bella et al., 2017; Zhao et al., 2019) \\
\hline & & Early age cracking & $\begin{array}{l}\text { (Khan, Xu, Castel, \& Gilbert, 2018; Safiuddin, Kaish, Woon, \& } \\
\text { Raman, 2018) }\end{array}$ \\
\hline & & Autogenous and drying shrinkage & (Gilbert, Castel, Khan, South, \& Mohammadi, 2018) \\
\hline \multirow{2}{*}{5} & \multirow{2}{*}{ 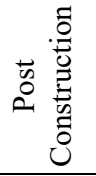 } & $\begin{array}{l}\text { Reinforcement and concrete } \\
\text { corrosion }\end{array}$ & (Shi, 2018; Zhou et al., 2018) \\
\hline & & $\begin{array}{l}\text { Internal crack occurrence and } \\
\text { propagation }\end{array}$ & (Cai, Fu, Shang, \& Shi, 2018; Dung, 2019) \\
\hline
\end{tabular}

Table 2. Application of sensors and IoT principles for lifecycle concrete monitoring at all stages

\begin{tabular}{|c|c|c|c|}
\hline Stage & Problem & $\begin{array}{l}\text { Sensor } \\
\text { Used }\end{array}$ & Description \\
\hline 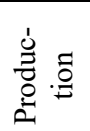 & $\begin{array}{l}\text { Quality control in } \\
\text { real time, material } \\
\text { wastage }\end{array}$ & $\begin{array}{l}\text { Moisture } \\
\text { Sensor }\end{array}$ & $\begin{array}{l}\text { Moisture sensor is placed in the concrete - to monitor water content (to prevent } \\
\text { excess addition of water during transportation), workability, and giving real- } \\
\text { time data of the chemical characteristics of concrete. }\end{array}$ \\
\hline 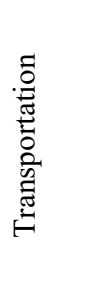 & $\begin{array}{l}\text { Unauthorized addi- } \\
\text { tion of water, cli- } \\
\text { matic conditions }\end{array}$ & $\begin{array}{l}\text { GPS, Smar- } \\
\text { tRock2 Sen- } \\
\text { sor, SONO- } \\
\text { WZ water- } \\
\text { cement ana- } \\
\text { lyser }\end{array}$ & $\begin{array}{l}\text { Transit mixers optimized using GPS monitoring. } \\
\text { Real-time monitoring of concrete w/c ratio through hydro-mix moisture sen- } \\
\text { sor for fresh concrete or SONO-WZ water-cement analyser for fresh concrete } \\
\text { would provide an effective practical solution to this problem (Tauqir, 2018). } \\
\text { Strength of concrete monitored through SmartRock2 sensor during different } \\
\text { stages of concrete life-cycle and effect of external factors on strength develop- } \\
\text { ment analyzed for the same concrete mix (Liu, Huang, Qiu, \& Shen, 2018). }\end{array}$ \\
\hline 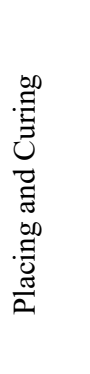 & $\begin{array}{l}\text { Concrete segrega- } \\
\text { tion, improper vi- } \\
\text { bration imparted } \\
\text { (over-compac- } \\
\text { tion/under-compac- } \\
\text { tion), placement } \\
\text { temperature, ther- } \\
\text { mal and early age } \\
\text { cracking, plastic } \\
\text { shrinkage }\end{array}$ & $\begin{array}{l}\text { Tempera- } \\
\text { ture and hu- } \\
\text { midity sen- } \\
\text { sors, viscos- } \\
\text { ity sensors }\end{array}$ & $\begin{array}{l}\text { Temperature and humidity sensors placed on the surface of the concrete at ran- } \\
\text { dom locations to cover the entire surface. One temperature sensor attached to } \\
\text { rebars to be embedded inside the concrete structure to monitor temperature dif- } \\
\text { ference between surface and core temperature of the concrete element. } \\
\text { Water flow controlled by Programmable Logic Circuit to start spray when } \\
\text { outside temperature is above } 45 \text { degrees Celsius or Relative Humidity is below } \\
80 \% \text { (Yang et al., 2018). } \\
\text { Viscosity sensors will monitor the real time workability of concrete ensure } \\
\text { optimization of vibration imparted. }\end{array}$ \\
\hline 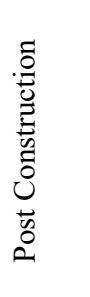 & $\begin{array}{l}\text { Reinforcement and } \\
\text { concrete corrosion, } \\
\text { internal crack oc- } \\
\text { currence and propa- } \\
\text { gation }\end{array}$ & $\begin{array}{l}\text { Pie- } \\
\text { zoceramic, } \\
\text { piezoelec- } \\
\text { tric sensors }\end{array}$ & $\begin{array}{l}\text { Piezoelectric/piezoceramic (PZT) patches (made of lead zirconate titanate) are } \\
\text { embedded, at pre-defined locations in the concrete structural element under } \\
\text { study. The structural element is put in a test-frame set-up using hydraulic actu- } \\
\text { ators for loading purposes. The sensor signal measured by a PZT sensor is de- } \\
\text { composed into sub-signals by the wavelet packet algorithm. The damage index } \\
\text { is calculated by comparing the energy vector of healthy state with the energy } \\
\text { vector of the damaged state. The damage index gives real-time information re- } \\
\text { garding occurrence and propagation of cracks (Song et al., 2007). }\end{array}$ \\
\hline
\end{tabular}

\section{Application of IoT techniques in the construction sector}

The Internet-of-Things (IoT) is a concept first coined around two decades back by Kevin Ashton in the context of supply chain management (Ashton, 2009). It is defined as a network of physical objects with sensing and communication capabilities that enable data synthesis and processing through seamless access to domain-specific software and services. The various IoT enabling technologies are categorized into the application, middleware, networking and ob- 
ject domains which make up the four broad layers of the IoT umbrella (Čolaković \& Hadžialić, 2018). IoT has increasingly started to pervade the construction industry, and researchers are trying to harness its various potential benefits (Ghosh, 2019).

\section{Conceptual framework - Digital Concrete Quality Control}

Table 2 shows the sensors used in the DCQC system to monitor the different parameters of concrete and solve many of the problems outlined in Table 1. Figure 2 depicts an overview of the conceptual framework and a model of the proposed dashboard that would provide an integrated tool that would facilitate real-time lifecycle monitoring of concrete at all stages.
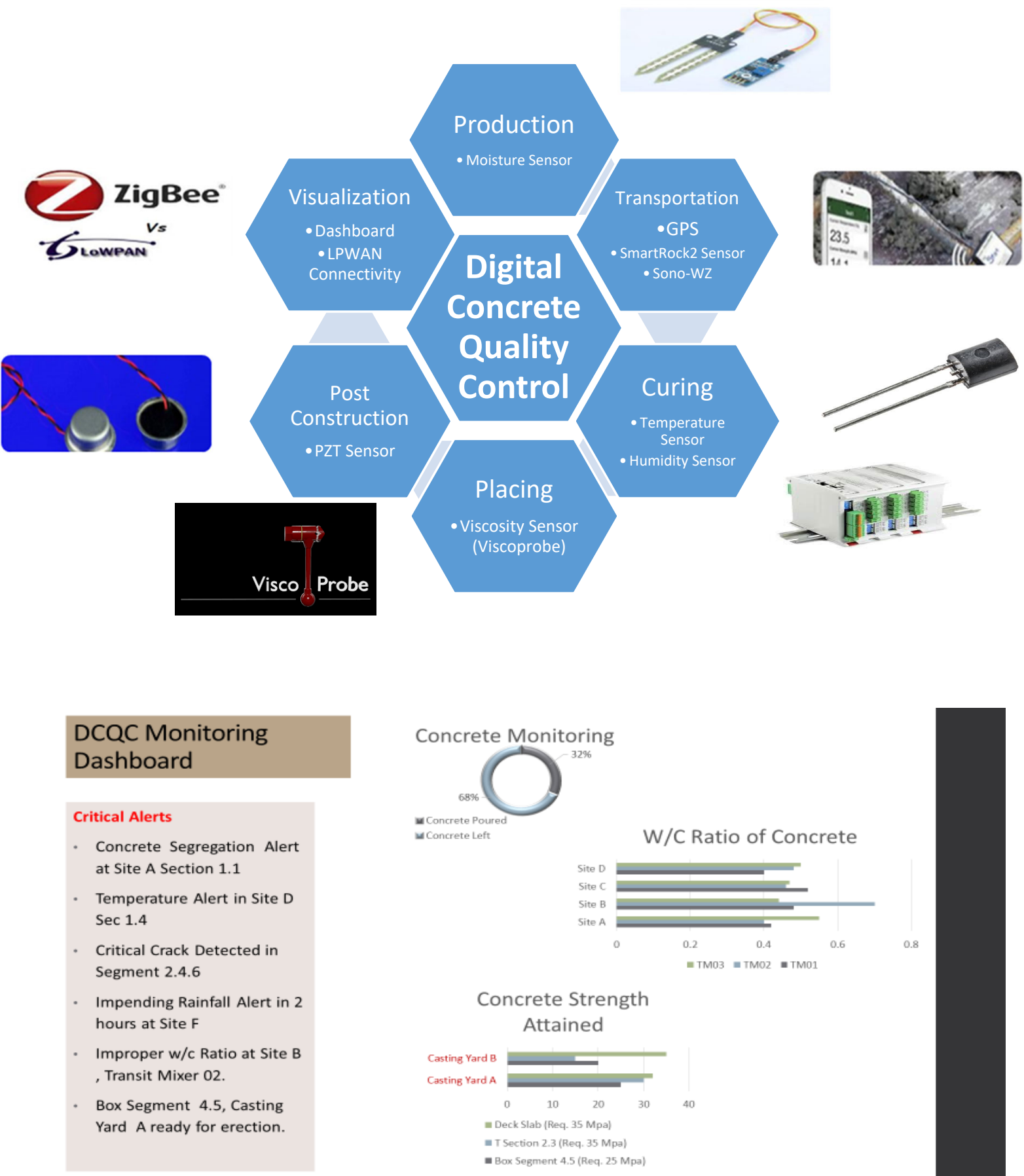

Figure 2. Proposed framework and Dashboard for Digital Concrete Quality Control (DCQC) monitoring 
All the sensors connected through LPWPAN (Low-Power Wide-Area Network, LoRa platform to for wide range connectivity (10 km radius). A suitable dashboard maybe developed for real-time monitoring the concrete placing, curing and rheological characteristics, giving critical alerts and suggesting predictive solutions whenever there is occurrence of critical cracks and greater stress produced in the concrete element (see Figure 2).

\section{Discussion}

Concreting operations constitute a crucial backbone for most construction activities (Jarkas, 2011). However, the concrete industry suffers from serious issues like low productivity (Australian Government, 2017) and quality conformance. The DCQC offers an innovative integrated system for real-time monitoring of concrete throughout its lifecycle and address the major issues outlined in Table 1.

Previous studies have tried to provide point solutions focussing on a single problem. This makes this study unique, as it proposes a methodology that addresses all current problems based on the capabilities provided by IoT. Though findings remain conceptual in nature, the study creates a ripe area for empirical research, namely, a direction for future research on the intersection of IoT and concrete activities by testing the practicality and operational aspects of implementing the proposed framework.

\section{Key benefits}

- Greatly assist construction managers to monitor concrete throughout its lifecycle;

- Reduce testing and retesting of concrete quality by managers and engineers (time savings);

- Reduce curing time and labour work hours;

- Prevention of unwanted addition of external substances (water) during transportation, make transit mixer operators more accountable;

- Allow maintenance engineers to have real-time monitoring of structures both inside and outside without resorting to expensive methods $\mathrm{x}$-ray spectroscopy for crack detection;

- One - time capital cost easily compensated by reusability in large projects;

- Ensures greater transparency between all stakeholders (contractor, client, worker, engineer);

- Saves valuable natural resource i.e. water and power (energy savings).

\section{References}

Afzal, S., \& Khan, R. K. (2018). A review paper on factors affecting ready-mix concrete delivery pattern. International Journal of Construction Engineering and Management, 7(3), 97-100.

Ashton, K. (2009). That 'internet of things' thing. RFID Journal, 22(7), 97-114.

Australian Government. (2017). Productivity and income - the Australian story, shifting the dial: 5 year productivity review (Supporting paper No. 1). Planning Commission, Commonwealth of Australia.

Bassani, M., Garcia, J. D., Meloni, F., Volpatti, G., \& Zampini, D. (2019). Recycled coarse aggregates from pelletized unused concrete for a more sustainable concrete production. Journal of Cleaner Production, 219, 424-432. https://doi.org/10.1016/j.jclepro.2019.01.338

Bella, N., Bella, I. A., \& Asroun, A. (2017). A review of hot climate concreting, and the appropriate procedures for ordinary jobsites in developing countries. In MATEC Web of Conferences (vol. 120, pp. 20-24). https://doi.org/10.1051/matecconf/201712002024

Cai, Y., Fu, X., Shang, Y., \& Shi, J. (2018). Methods for long-distance crack location and detection of concrete bridge structures. In IEEE $3^{\text {rd }}$ International Conference on Image, Vision and Computing (ICIVC) (pp. 576-580). https://doi.org/10.1109/ICIVC.2018.8492764

Čolaković, A., \& Hadžialić, M. (2018). Internet of Things (IoT): a review of enabling technologies, challenges, and open research issues. Computer Networks, 144, 17-39.

Dung, C. V. (2019). Autonomous concrete crack detection using deep fully convolutional neural network. Automation in Construction, 99, 52-58. https://doi.org/10.1016/j.autcon.2018.11.028

Gao, X., Zhang, J., \& Su, Y. (2019). Influence of vibration-induced segregation on mechanical property and chloride ion permeability of concrete with variable rheological performance. Construction Building Materials, 194, 32-41. https://doi.org/10.1016/j.conbuildmat.2018.11.019

Gardner, D., Lark, R., Jefferson, T., \& Davies, R. (2018). A survey on problems encountered in current concrete construction and the potential benefits of self-healing cementitious materials. Case Studies in Construction Materials, 8, 238-247. https://doi.org/10.1016/j.cscm.2018.02.002

Ghosh, A. (2019). Review of application of IoT techniques in construction sector. Retrieved from https://deakin365my.sharepoint.com/:b:/g/personal/ghoshar_deakin_edu_au/EcQUgQQLcNRFmIcFvAnMpLcBrV8HWDnbY98pOTN4eZ11Q? $=$ PtheTV 
Ghosh, A., Hasan, A., Jha, K. N., \& Sahoo, N. R. (2018). Factors influencing productivity of concreting equipment in Indian construction projects. Paper presented at the Proceedings of the $10^{\text {th }}$ Conference on Construction Industry in the Twenty-first Century. Colombo, Sri Lanka.

Ghourchian, S., Wyrzykowski, M., Baquerizo, L., \& Lura, P. (2018). Susceptibility of Portland cement and blended cement concretes to plastic shrinkage cracking. Cement and Concrete Composites, 85, 44-55. https://doi.org/10.1016/j.cemconcomp.2017.10.002

Gilbert, R. I., Castel, A., Khan, I., South, W., \& Mohammadi, J. (2018). An experimental study of autogenous and drying shrinkage. In D. Hordijk, \& M. Luković (Eds), High tech concrete: where technology and engineering meet (pp. 33-41). Cham: Springer. https://doi.org/10.1007/978-3-319-59471-2 5

Ha, J. H., Su-Jung, Y., \& Cho, Y. G. (2014). Thermal crack control in mass concrete structure using an automated curing system. Automation in Construction, 45, 16-24. https://doi.org/10.1016/j.autcon.2014.04.014

Hasan, A., Sahoo, N. R., Ghosh, A., \& Jha, K. N. (2018). A queuing model to improve the utilization of concreting equipment. Paper presented at the Proceedings of $23^{\text {rd }}$ International Symposium on Advancement of Construction Management and Real Estate, Guiyang, China.

Howes, R., Hadi, M. N., \& South, W. (2019). Concrete strength reduction due to over compaction. Construction and Building Materials, 197, 725-733. https://doi.org/10.1016/j.conbuildmat.2018.11.234

Jarkas, A. M. (2011). Buildability factors influencing concreting labor productivity. Journal of Construction Engineering and Management, 138(1), 89-97. https://doi.org/10.1061/(ASCE)CO.1943-7862.0000404

Juliafad, E., Rani, I. G., \& Rifwan, F. (2019). Concreting workmanship in Indonesia study case: Padang City, West Sumatra, Indonesia. International Journal on Advanced Science, Engineering and Information Technology, 9(1), 300-306. https://doi.org/10.18517/ijaseit.9.1.7201

Justs, J., Wyrzykowski, M., Bajare, D., \& Lura, P. (2015). Internal curing by superabsorbent polymers in ultra-high performance concrete. Cement Concrete Research, 76, 82-90. https://doi.org/10.1016/j.cemconres.2015.05.005

Kewalramani, M. A. (2014). Environmentally sustainable concrete curing with coloured polythene sheets. APCBEE Procedia, 9 , 241-246. https://doi.org/10.1016/j.apcbee.2014.01.043

Khan, I., Xu, T., Castel, A., \& Gilbert, R. I. (2018). Early-age tensile creep and shrinkage induced cracking in internally restrained concrete members. Magazine of Concrete Research, 1-13. https://doi.org/10.1680/jmacr.18.00038

Kinable, J., Wauters, T., \& Berghe, G. V. (2014). The concrete delivery problem. Computers and Operations Research, 48, 53-68. https://doi.org/10.1016/j.cor.2014.02.008

Klee, H. (2009). The cement sustainability initiative: recycling concrete. World Business Council for Sustainable Development. Geneva, Switzerland.

Korkmaz, H. H., Yakut, A., \& Bayraktar, A. (2019). Analysis of a multi-story reinforced concrete residential building damaged under its self-weight. Engineering Failure Analysis, 98, 38-48. https://doi.org/10.1016/j.engfailanal.2019.01.043

Liu, S., Huang, H., Qiu, T., \& Shen, S. (2018). Sensing mechanism and real-time computing for granular materials. Journal of Computing in Civil Engineering, 32(4), 04018023. https://doi.org/10.1061/(ASCE)CP.1943-5487.0000769

Niu, Y., Lu, W., Liu, D., Chen, K., \& Xue, F. (2017). A smart construction object (SCO)-Enabled proactive data management system for construction equipment management. Computing in Civil Engineering, 130-138. https://doi.org/10.1061/9780784480830.017

Ouyang, J., Chen, X., Huangfu, Z., Lu, C., Huang, D., \& Li, Y. (2019). Application of distributed temperature sensing for cracking control of mass concrete. Construction and Building Materials, 197, 778-791. https://doi.org/10.1016/j.conbuildmat.2018.11.221

Pan, X., Shi, Z., Shi, C., Ling, T. C., \& Li, N. (2017). A review on concrete surface treatment Part I: types and mechanisms. Construction Building Materials, 132, 578-590. https://doi.org/10.1016/j.conbuildmat.2016.12.025

Paré, G., Trudel, M.-C., Jaana, M., \& Kitsiou, S. (2015). Synthesizing information systems knowledge: a typology of literature reviews. Information Management, 52(2), 183-199. https://doi.org/10.1016/j.im.2014.08.008

Ramasundara, Y., Johnson, A., \& Baumeister, D. (2018). Australia's IoT opportunity: driving future growth an ACS report. ACS.

Rattanadecho, P., Makul, N., Pichaicherd, A., Chanamai, P., \& Rungroungdouyboon, B. (2016). A novel rapid microwave-thermal process for accelerated curing of concrete: prototype design, optimal process and experimental investigations. Construction Building Materials, 123, 768-784. https://doi.org/10.1016/j.conbuildmat.2016.07.084

Reiter, L., Wangler, T., Roussel, N., \& Flatt, R. J. (2018). The role of early age structural build-up in digital fabrication with concrete. Cement and Concrete Research, 112, 86-95. https://doi.org/10.1016/j.cemconres.2018.05.011

Rockstroh, B. A. (2018). An investigation into the effects of early propping removal on the deflection of reinforced concrete beams (Doctoral dissertation). University of Cape Town.

Safawi, M. I., Iwaki, I., \& Miura, T. (2004). The segregation tendency in the vibration of high fluidity concrete. Cement Concrete Research, 34(2), 219-226. https://doi.org/10.1016/S0008-8846(03)00249-7

Safiuddin, M., Kaish, A., Woon, C. O., \& Raman, S. (2018). Early-age cracking in concrete: causes, consequences, remedial measures, and recommendations. Applied Sciences, 8(10), 1730-1734. https://doi.org/10.3390/app8101730

Samouh, H., Rozière, E., \& Loukili, A. (2015). Influence of formwork duration on the shrinkage, microstructure, and durability of cement-based materials. CONCREEP, 10, 1119-1128. https://doi.org/10.1061/9780784479346.134 
Ghosh, A.; Hosseini, M. R.; Al-Ameri, R.; Kaklauskas, G.; Nikmehr, B. 2019.

Internet of Things (IoT) for digital concrete quality control (DCQC): A conceptual framework

Sheikh, A., Lakshmipath, M., \& Prakash, A. (2016). Application of queuing theory for effective equipment utilization and maximization of productivity in construction management. International Journal of Applied Engineering Research, 11(8), 5664-5672.

Shi, X. (2018). Monitoring of reinforced concrete corrosion. In Eco-efficient repair and rehabilitation of concrete infrastructures (pp. 69-95). Elsevier. https://doi.org/10.1016/B978-0-08-102181-1.00004-6

Sitnikov, V. (2018). Ice formwork for high-performance concrete: a model of lean production for prefabricated concrete industry. Structures, 18, 109-116. https://doi.org/10.1016/j.istruc.2018.11.004

Song, G., Gu, H., Mo, Y., Hsu, T., \& Dhonde, H. (2007). Concrete structural health monitoring using embedded piezoceramic transducers. Smart Materials Structures, 16(4), 959-965. https://doi.org/10.1088/0964-1726/16/4/003

Surahyo, A. (2019). Hot and cold weather concreting. In Concrete construction (pp. 257-272). Cham: Springer. https://doi.org/10.1007/978-3-030-10510-5_11

Tauqir, A. (2018). Determination of water/cement-ratio of cement (Master of Science in Engineering thesis). Aalto University.

Wei, Y., Lin, J., Zhao, W., Hou, C., Yu, Z., Qiao, M., \& Liu, B. (2018). An internet based intelligent system for early concrete curing in underground structures. In Proceedings of China-Europe Conference on Geotechnical Engineering (pp. 743-746.) https://doi.org/10.1007/978-3-319-97112-4_166

Yang, J., Fan, J., Kong, B., Cai, C. S., \& Chen, K. (2018). Theory and application of new automated concrete curing system. Journal of Building Engineering, 17, 125-134. https://doi.org/10.1016/j.jobe.2018.02.009

Zhao, Z., Wang, K., Lange, D. A., Zhou, H., Wang, W., \& Zhu, D. (2019). Creep and thermal cracking of ultra-high volume fly ash mass concrete at early age. Cement and Concrete Composites, 99, 191-202. https://doi.org/10.1016/j.cemconcomp.2019.02.018

Zhou, M., Liao, J., An, L., Deng, W., Hassanein, M. F., \& Yu, Z. (2018). Analysis of stress-induced cracks in concrete and mortar under cyclic uniaxial compression. Construction Building Materials, 187, 652-664.

https://doi.org/10.1016/j.conbuildmat.2018.07.219 